\title{
Effects of Palm Oil Consumption on Lipidic and Lipidoproteinic Profiles in Patients Suffering from Ischemic Heart Pathologies
}

\author{
Monde Aké Absalome ${ }^{1,}$, , Camara-Cisse Massara ${ }^{1}$, Konan Gervais ${ }^{1}$, Coulibaly Iklo ${ }^{2}$, \\ Adeoti Mansour ${ }^{1}$, Gauze-Gnagne-Agnero Chantal ${ }^{1}$, Djohan Ferdinand ${ }^{1}$, Emien Kouatchi Sylvain ${ }^{1}$, \\ Niamke Germaine ${ }^{1}$, Hauhouot-Attoungbre Marie-Laure ${ }^{3}$ \\ ${ }^{1}$ Medical Biochemistry Laboratory, School of Medical Sciences, University Felix HOUPHOUET-BOIGNY, Abidjan, Côte d'Ivoire \\ ${ }^{2}$ Service of Medicine, Institute of Cardiology, Abidjan, Côte d'Ivoire \\ ${ }^{3}$ Biochemistry Laboratory of the Institute of Cardiology, Abidjan, Côte d'Ivoire
}

Email address:

monde_abs@yahoo.fr (M. A. Absalome)

${ }^{*}$ Corresponding author

\section{To cite this article:}

Monde Aké Absalome, Camara-Cisse Massara, Konan Gervais, Coulibaly Iklo, Adeoti Mansour, Gauze-Gnagne-Agnero Chantal, Djohan Ferdinand, Emien Kouatchi Sylvain, Niamke Germaine, Hauhouot-Attoungbre Marie-Laure. Effects of Palm Oil Consumption on Lipidic and Lipidoproteinic Profiles in Patients Suffering from Ischemic Heart Pathologies. International Journal of Nutrition and Food Sciences. Vol. 6, No. 1, 2017, pp. 6-11. doi: 10.11648/j.ijnfs.20170601.12

Received: October 19, 2016; Accepted: November 22, 2016; Published: December 26, 2016

\begin{abstract}
Because of its content of saturated fatty acids, palm oil is often considered as being atherogenic nutritionally, and would therefore purveyor of certain diseases including cardiovascular disease. The present study was conducted to assess changes in the lipid profile and lipoprotein of patients with ischemic heart, consumers versus non-consumers of palm oil. The study involved 120 patients enrolled at the Cardiology Institute of Abidjan, divided into 3 groups. Group 1 consisted of 50 patients consumers of refined palm oil, group 2, of 40 patients taking the two forms of oil (refined and raw red), and group 3 comprised 30 patients not consuming palm oil (control group). The lipid parameters and lipoprotein measured were total cholesterol, triglycerides, HDL and LDL cholesterol, and the atherogenic index. In patient's consumers of refined palm oil, after 04 weeks of diet, $58 \%$ had normal cholesterol rate, $14 \%$ hypercholesterolemia and $28 \%$ with low cholesterol rate. As for patients taking both types of palm oil, $57.50 \%$ had normal cholesterol rate, $15 \%$ hypercholesterolemia and $27.50 \%$ with low cholesterol rate. Patients, non-consumers of palm oil had low cholesterol rate at $26.67 \%$. The difference was not significant. Whatever the form of consumption, we notice a variation in the cholesterol rate as well as a tendency of low cholesterol rate after four weeks of dieting, with no significant difference. The same pattern was observed with the dosages of triglycerides, LDL cholesterol, HDL cholesterol and atherogenic index, for which changes were also not significant in the 03 groups. The consumption or not of palm oil, whatever the form and the duration of consumption, had no significant influence on serum lipid and lipoprotein parameters and the atherogenic index of patients carriers of ischemic heart disease. This study, although preliminary, has allowed determining that palm oil is harmless in patients with ischemic heart disease, consumers or non consumers of that oil.
\end{abstract}

Keywords: Palm Oil, Ischemic Heart Disease, Lipid Profile, Lipoprotein, Atherogenic Index

\section{Introduction}

The ischemic heart disease or coronary artery disease is a major cause of death worldwide [1], which is expanding in developing countries $[2,3]$ namely in Côte d'Ivoire, where its occurrence has been pointed out for several years [4]. Many factors may be responsible for the decrease in the oxygen supply, including organic obstructions [5], caused by 
cholesterol deposits build up (atherosclerotic plaque), calcium and other substances carried by the blood. These deposits gradually narrow the coronary arteries depriving some parts of the heart with blood and oxygen, which therefore results in an ischemia [6]. In order to prevent the occurrence of cardiovascular disease, or limit their growth, some patients are recommended not to consume food that can increase the cholesterol content, so the atherogenic risk. Among these fatty foods, palm oil is the most often mentioned because of its saturated fatty acids content, said to be source of atherogenic and therefore would purveyor certain diseases, including cardiovascular disease [7-10]. Works on the assessment of knowledge on the nutritional values of palm oil have shown that this oil was advised against by medical as well as paramedical staffs for hypertensive patients with ischemic heart disease, respectively $56 \%$ and $4313 \%[11,12]$, because it is said to be responsible for hypercholesterolemia. Several studies have shown the beneficial effects of the consumption of palm oil on health [13-16], and particularly in Côte d'Ivoire. Although these studies have shown the benefits of the consumption of this oil, as well as its antioxidant properties [17-19], no work has focused on the changes in the lipid profile and lipoprotein among patient's consumers of palm oil, whereas this country is, after Nigeria, Africa's second largest producer of palm oil and the largest exporter of this commodity. [20] This work thus intends to study the changes in the lipid parameters and lipoprotein in patients with ischemic heart disease, consumers or non consumers of palm oil, in order to establish the relationship between the consumption of palm oil and the occurrence of cardiovascular risk within the studied population.

\section{Methodology}

Adult patients of both sexes, with ischemic heart disease, enrolled in the Cardiology Institute of Abidjan, were divided into 3 groups. Group 1 consisted of 50 patients consumers of refined palm oil; group 2, of 40 patients taking the two types of oil (refined and raw red); and, group 3 comprised 30 patients non consumers of palm oil (control group). Regarding the oil consumption, the recommended intakes were calculated based on the weight of each patient, while explaining to those accompanied by their wives (for men in couples), the oil quantity equivalence: $25 \mathrm{~g}$ of oil corresponded roughly to 2 tablespoons. [21, 22]. The lipid needs are $1 \mathrm{~g} / \mathrm{kg}$ of body weight / day (1 gram of fat contains 9 calories), and these fats represent 20 to $30 \%$ of the 2,500 Kcal. According to the nutritional recommendations, the average adult (total metabolism of 2,500 kcal) should consume about 100 grams of fat per day (i.e. $20 \%$ to $30 \%$ of the total daily intake). A total of 120 known patients under treatment were asked to follow the usual diet for a total of 4 weeks. The diet included refined palm oil, commonly consumed in the area of Abidjan, the two types of palm oil (refined and raw red in daily equal amounts), and another vegetable oil for non consumers of palm oil. The alcoholsmoking patients as well as those with liver disease were not included.

\subsection{Biological Parameters Analyzed}

The total cholesterol, triglycerides, HDL-cholesterol were measured in the 3 groups by conventional enzymatic methods in patients during the admission time and after 04 weeks of diet, that after 10 to 12 hours of fasting. The LDLcholesterol were calculated using the Friedwald formula. The relationship total cholesterol-HDL was used to assess the risk of atherogenesis. These dosages were performed in the laboratory of Biochemistry of the Institute of Cardiology of in Abidjan using Roche's automated random "COBAS INTEGRA 400". The parameters were interpreted taking into account the reference values in healthy Ivorian [23], where normal cholesterol ranges from 1.5 to $2.2 \mathrm{~g} / \mathrm{l}$; normal triglyceride: 0,4 to $1.4 \mathrm{~g}$; normal HDL (high): $>0.4 \mathrm{~g} / 1$; LDL cholesterol: normal: $<1.7 \mathrm{~g} / 1$.

\subsection{Consent}

We had had a clear and free consent of each patient before starting the study

\subsection{Statistical Tests}

The statistical tests utilized were the Fisher and Khi-deux Tests at a threshold of $5 \%$.

Table 1. Variations of the lipidic and lipoprotein serum parameters in patients, consumers or non consumers of palm oil during admission before dieting.

\begin{tabular}{|c|c|c|c|c|c|c|}
\hline \multirow{2}{*}{$\begin{array}{l}\text { Lipidic and Lipoprotein } \\
\text { Parameters }\end{array}$} & \multirow{2}{*}{$\begin{array}{l}\text { Palm oil Consumption versus non } \\
\text { Consumption }\end{array}$} & & \multicolumn{3}{|c|}{ Variations of Lipidic and Lipoprotein Parameters } & \multirow{2}{*}{$\mathbf{P}$} \\
\hline & & & Low & Normal & High & \\
\hline \multirow{6}{*}{ Total Cholesterolemia } & \multirow{2}{*}{ Group $1(\mathrm{n}=50)$} & $\mathrm{n}$ & 10 & 31 & 9 & \multirow{6}{*}{0.858} \\
\hline & & $\%$ & 20 & 62 & 18.00 & \\
\hline & & $\mathrm{n}$ & 8 & 24 & 8 & \\
\hline & Group $2(n=40)$ & $\%$ & 20.00 & 60.00 & 20.00 & \\
\hline & & $\mathrm{n}$ & 5 & 18 & 7 & \\
\hline & Group $3(\mathrm{n}=30)$ & $\%$ & 16.67 & 60 & 23.33 & \\
\hline \multirow{6}{*}{ Triglyceridemia } & \multirow{2}{*}{ Group $1(\mathrm{n}=50)$} & $\mathrm{n}$ & 1 & 46 & 3 & \multirow{6}{*}{0.077} \\
\hline & & $\%$ & 2.50 & 92.50 & 5.00 & \\
\hline & Groun $2(n=40)$ & $\mathrm{n}$ & 0 & 38 & 02 & \\
\hline & \multirow{3}{*}{ Group $3(n=30)$} & $\%$ & 0.00 & 95.00 & 05.00 & \\
\hline & & $\mathrm{n}$ & 0 & 26 & 4 & \\
\hline & & $\%$ & 0.00 & 86.66 & 13.33 & \\
\hline
\end{tabular}




\begin{tabular}{|c|c|c|c|c|c|c|}
\hline \multirow{2}{*}{$\begin{array}{l}\text { Lipidic and Lipoprotein } \\
\text { Parameters }\end{array}$} & \multirow{2}{*}{$\begin{array}{l}\text { Palm oil Consumption versus non } \\
\text { Consumption }\end{array}$} & & \multicolumn{3}{|c|}{ Variations of Lipidic and Lipoprotein Parameters } & \multirow{2}{*}{$\mathbf{P}$} \\
\hline & & & Low & Normal & High & \\
\hline \multirow{6}{*}{ HDL cholesterol } & \multirow{2}{*}{ Group $1(\mathrm{n}=50)$} & $\mathrm{n}$ & 15 & - & 35 & \multirow{6}{*}{0.638} \\
\hline & & $\%$ & 30.00 & - & 70.00 & \\
\hline & \multirow{2}{*}{ Group $2(n=40)$} & $\mathrm{n}$ & 12 & - & 28 & \\
\hline & & $\%$ & 30.00 & - & 70.00 & \\
\hline & \multirow{2}{*}{ Group $3(n=30)$} & $\mathrm{n}$ & 9 & - & 21 & \\
\hline & & $\%$ & 30 & - & 70 & \\
\hline \multirow{6}{*}{ LDL cholesterol } & \multirow{2}{*}{ Group $1(\mathrm{n}=50)$} & $\mathrm{n}$ & - & 48 & 2 & \multirow{6}{*}{0.496} \\
\hline & & $\%$ & - & 96.00 & 4.00 & \\
\hline & Groun $2(n=40)$ & $\mathrm{n}$ & - & 36 & 4 & \\
\hline & Group $2(n=40)$ & $\%$ & - & 90.00 & 10.00 & \\
\hline & \multirow{2}{*}{ Group $3(n=30)$} & $\mathrm{n}$ & - & 25 & 5 & \\
\hline & & $\%$ & - & 83.33 & 16.67 & \\
\hline
\end{tabular}

The variations in the lipid and lipoprotein parameters were not significant in both palm oil consumers (refined and the 2 types) and non palm oil consumers, in the initial assessment of the patients.

Table 2. Comparaison des paramètres lipidiques et lipoprotéiniques sériques chez les consommateurs versus non consommateurs d'huile de palme après quatre semaines de régime Comparison of the lipidic and lipoprotein serum parameters in patients, consumers or non consumers of palm oil after 04 weeks of diet.

\begin{tabular}{|c|c|c|c|c|c|c|c|}
\hline \multirow{2}{*}{$\begin{array}{l}\text { Lipidic and Lipoprotein } \\
\text { Parameters }\end{array}$} & \multirow{2}{*}{\multicolumn{2}{|c|}{$\begin{array}{l}\text { Palm oil Consumption versus non } \\
\text { Consumption }\end{array}$}} & \multicolumn{4}{|c|}{ Variations of Lipidic and Lipoprotein Parameters } & \multirow{2}{*}{$\mathbf{P}$} \\
\hline & & & Low & Normal & High & Total & \\
\hline \multirow{6}{*}{ Total Cholesterolemia } & \multirow{2}{*}{ Group $1(n=50)$} & $\mathrm{n}$ & 14 & 29 & 7 & 50 & \multirow{6}{*}{0.936} \\
\hline & & $\%$ & 28 & 58 & 14 & 100 & \\
\hline & \multirow{2}{*}{ Group $2(\mathrm{n}=40)$} & $\mathrm{n}$ & 11 & 23 & 6 & 40 & \\
\hline & & $\%$ & 27.50 & 57.50 & 15 & 100 & \\
\hline & \multirow{2}{*}{ Group $3(n=30)$} & $\mathrm{n}$ & 08 & 17 & 05 & 30 & \\
\hline & & $\%$ & 26.67 & 56.67 & 16.67 & 100 & \\
\hline \multirow{6}{*}{ Triglyceridemia } & \multirow{2}{*}{ Group $1(n=50)$} & $\mathrm{n}$ & 3 & 43 & 4 & 50 & \multirow{6}{*}{0.271} \\
\hline & & $\%$ & 6 & 86 & 8 & 100 & \\
\hline & Groun $2(n=40)$ & $\mathrm{n}$ & 1 & 35 & 4 & 40 & \\
\hline & Group $\angle(n=40)$ & $\%$ & 2.50 & 87.50 & 10 & 100 & \\
\hline & \multirow{2}{*}{ Group $3(\mathrm{n}=30)$} & $\mathrm{n}$ & 0 & 27 & 3 & 30 & \\
\hline & & $\%$ & 0 & 90 & 10 & 100 & \\
\hline \multirow{6}{*}{ HDL cholesterol } & \multirow{2}{*}{ Group $1(\mathrm{n}=50)$} & $\mathrm{n}$ & 9 & - & 41 & 50 & \multirow{6}{*}{0.009} \\
\hline & & $\%$ & 18 & - & 82 & 100 & \\
\hline & Groun $2(n=40)$ & $\mathrm{n}$ & 08 & - & 32 & 40 & \\
\hline & & $\%$ & 20 & - & 80 & 100 & \\
\hline & \multirow{2}{*}{ Group $3(n=30)$} & $\mathrm{n}$ & 07 & - & 23 & 30 & \\
\hline & & $\%$ & 23.33 & - & 76.67 & 100 & \\
\hline \multirow{6}{*}{ LDL cholesterol } & \multirow{2}{*}{ Group $1(\mathrm{n}=50)$} & $\mathrm{n}$ & - & 49 & 1 & 50 & \multirow{6}{*}{0.14} \\
\hline & & $\%$ & - & 98 & 2 & 100 & \\
\hline & \multirow{2}{*}{ Group $2(n=40)$} & $\mathrm{n}$ & - & 39 & 1 & 40 & \\
\hline & & $\%$ & - & 97.5 & 2.5 & 100 & \\
\hline & \multirow{2}{*}{ Group $3(n=30)$} & $\mathrm{n}$ & - & 25 & 5 & 30 & \\
\hline & & $\%$ & - & 83.33 & 16.67 & 100 & \\
\hline
\end{tabular}

The variations in the lipid and lipoprotein parameters were not significant in both palm oil consumers and non consumers after 04 weeks of dieting. Nota Bene: atherogenesis index: normal: $<5$; Abnormal : $>5$

The consumption or not of palm oil has no significant influence on the atherogenesis index in the initial assessment after 04 weeks of dieting.

Table 3. Consumption or non consumption of palm oil and types of consumption during admission and after 04 weeks.

\begin{tabular}{|c|c|c|c|c|c|}
\hline \multirow{2}{*}{\multicolumn{3}{|c|}{$\begin{array}{l}\text { Consumption or non consumption of palm oil and types of consumption during } \\
\text { admission and after } 04 \text { weeks }\end{array}$}} & \multicolumn{2}{|l|}{ CT/HDL } & \multirow{2}{*}{$\mathbf{P}$} \\
\hline & & & Normal $(<5)$ & Abnormal (>5) & \\
\hline \multirow{6}{*}{$\begin{array}{l}\text { Consumption vs. non Consumption } \\
\text { of palm oil during admission }\end{array}$} & \multirow{2}{*}{ Refined palm oil $(\mathrm{n}=50)$} & $\mathrm{n}$ & 26 & 24 & \multirow{6}{*}{0.548} \\
\hline & & $\%$ & 52 & 48 & \\
\hline & \multirow{2}{*}{ The 2 Types $(\mathrm{n}=40)$} & $\mathrm{n}$ & 20 & 20 & \\
\hline & & $\%$ & 50 & 50 & \\
\hline & \multirow{2}{*}{ Non consumers $(n=30)$} & $\mathrm{n}$ & 16 & 14 & \\
\hline & & $\%$ & 53.33 & 46.67 & \\
\hline \multirow{6}{*}{$\begin{array}{l}\text { Consumption vs. non Consumption } \\
\text { of palm oil after } 04 \text { weeks }\end{array}$} & \multirow{2}{*}{ Refined palm oil $(\mathrm{n}=50)$} & $\mathrm{n}$ & 30 & 20 & \multirow{6}{*}{0.372} \\
\hline & & $\%$ & 60 & 40 & \\
\hline & The 2 Tynes $(\mathrm{n}=40)$ & $\mathrm{n}$ & 25 & 15 & \\
\hline & Ine 2 1 ypes $(n=40)$ & $\%$ & 62.5 & 37.5 & \\
\hline & \multirow{2}{*}{ Non consumers $(n=30)$} & $\mathrm{n}$ & 18 & 12 & \\
\hline & & $\%$ & 60 & 40 & \\
\hline
\end{tabular}




\section{Results and Discussion}

\subsection{At the Socio-Epidemiolocal Level}

Patients had an average age of 57.34 years with a sex ratio of 1.13. Our results are similar to those of Bertrand et al [24] in which the mean ages were 55 and 56 years respectively. The average age generally corresponds to the age range of onset of major chronic diseases, including diabetes and hypertension. Most of the patients had a hypertension history either personally or at the family level. This could be explained by the Framingham study quoted by Froment [25], which showed that the risk of hypertensive subjects compared to subjects with normal blood pressure was tripled for ischemic heart disease, doubled to arteritis, and multiplied by five for congestive heart failure. Hypertension is a major risk factor for the onset of ischemic heart disease. It would make sense to support these patients.

\subsection{Concerning the Consumption or Non Consumption of Palm Oil}

In Côte d'Ivoire, palm oil is the primary oil used in households, which would explain its high consumption. The refined palm oil mainly consumed, mostly sold, and easily accessible has emerged as cooking and frying oil in all types of food preparation in the tropics in particular $[16,20,26]$. Patients who do not consume palm oil would probably have received advice to stop it as reported by other studies $[11,12$, $27,28]$, claiming that palm oil would deteriorate or aggravate their condition.

\subsection{Lipid and Lipoprotein Parameters Variations}

Relationship between total cholesterolemia and consumption or non consumption of palm oil:

Among those patients with refined palm oil, 62\% had normal cholesterol, 20\% hypocholesterolemia and $18 \%$ hypercholesterolemia. In patients who consume both forms of palm oil, the cholesterol was normal in $60 \%$ of cases, decreased in $20 \%$ and was high in $20 \%$ of cases. In patient's non consumers of palm oil, the cholesterol was normal in $60 \%$ of cases, $23.33 \%$ had hypercholesterolemia and $16.67 \%$ hypocholesterolemia. The difference was not significant. After 04 weeks of dieting, 58\% of patient's consumers of refined palm oil had normal cholesterol, 14\% hypercholesterolemia and $28 \%$ lower in cholesterol. As for patients taking both forms of palm oil, $57.50 \%$ had normal cholesterol, $15 \%$ hypercholesterolemia and $27.50 \%$ hypocholesterolemia. Non-consumers of palm oil patients had hypocholesterolemia at $26.67 \%$. The difference here also was not significant. Whatever the form of consumption, we see a variation of cholesterol in the same direction with a tendency to hypocholesterolemia after four weeks of dieting, with no significant difference. Our results are consistent with those of Pacetti et al. [14] who showed stabilization or even a decrease in the total cholesterol among patient's consumers of palm oil. Similarly, Ebong [16] demonstrated the influence of palm oil in lowering the total cholesterol. This change was similar to those of patients who consumed refined palm oil and both forms, without a significant difference. Thus, no matter whether patients consume refined palm oil, both forms of palm oil that did not influence their serum cholesterol levels. Our results are in line with those of Onyeali et al. [29], which had shown the beneficial effects of the consumption of palm oil on the plasma lipid profile in Wistar rats. They showed that the consumption of palm oil had led to a significant reduction in the total cholesterol compared with control groups. Ladeia et al. [30] also demonstrated in subjects fed on palm oil, a significant reduction in blood cholesterol levels. Zhang et al. [31] had assessed the effect of palm oil used in the Chinese diets compared to soybean oil, peanut oil and lard. They demonstrated that diets containing palm oil had reduced significantly the serum cholesterol levels of subjects as opposed to the lard, but comparable to soybean oil effect mainly polyunsaturated. Basu et al. [32] in India had also shown the role of palm oil in lowering the total cholesterol.

\subsection{Relationship Between Triglyceridemia and Consumption or Non Consumption of Palm Oil}

Triglycerides were normal: $92.5 \%, 95 \%$ and $86.66 \%$ respectively in patients who consume refined palm oil, the two forms of oil in non-consumers, this during admission before the diet. After 04 weeks of dieting, the triglyceride level was also normal: $86 \%, 87.5 \%$ and $90 \%$ respectively in patients who consume refined palm oil, both forms of palm oil and non-consumers. Thus, triglycerides were normal in consumers of refined palm oil as well as in the two forms of consumption, with no significant difference. Onyeali et al. [29] pointed out a significant reduction in triglycerides, as well as Zhang et al. [31], Arenceta et al [33] who demonstrated the influence of palm oil consumption in the reduction or normalization of serum triglycerides. The work of Sundram [14] and Ebong [16] had also shown that palm oil consumption does not significantly influenced triglycerides subjects.

\subsection{Relationship Between HDL Cholesterol and Consumption or Non Consumption of Palm Oil}

During admission, $70 \%$ of both patient's consumers of refined palm oil and the two forms of oil had high HDL cholesterol levels. After 04 weeks of dieting, the HDL cholesterol levels were even higher, respectively $82 \%, 80 \%$ and $76.67 \%$ in patients who consumed refined palm oil, both forms of oil and non palm oil consumers. Patients with normal HDL cholesterol that is to say high, up almost $70 \%$ in the 3 groups, with no significant difference led us to say that the consumption or not of palm oil did not influence significantly the HDL cholesterol levels. In addition, Onyeali et al. [29] showed that diet containing palm oil had no significant effect on serum HDL cholesterol levels. Similarly, Boon et al [36] had reported a rise in HDL cholesterol in 
patient's consumers of palm oil. This suggests the beneficial effect of the consumption of palm oil. The HDL cholesterol, conventionally called "good cholesterol", vehicles the cholesterol from tissues to the liver for elimination. Thus, a low level of HDL cholesterol is a risk factor, but on the contrary a higher or normal rate is viewed as cardioprotective $[33,35,36]$.

\subsection{Relationship Between LDL Cholesterol and Consumption or Non Consumption of Palm Oil}

During admission, the LDL cholesterol was normal in $96 \%$, $90 \%$ and $83.33 \%$ of consumers (refined palm oil and both forms) and non consumers, respectively. After 04 weeks of dieting, $98 \%$ and $97.5 \%$ of consumers of refined palm oil and the two forms had normal levels of LDL cholesterol, without significant difference. In non consumers of palm oil, the LDL cholesterol did not varied significantly, as well. Thus, the LDL cholesterol was lowered or normal among in the refined palm oil consumers as well as in the two forms, with no significant difference. Onyeali et al. [29] had also showed that the consumption of palm oil had led to a significant reduction in LDL cholesterol, which decrease is also reported by other studies [33-35].

\subsection{Relationship Between Palm Oil and the Atherogenesis Index}

The atherogenic index, defined as the ratio between the total cholesterol and the HDL should be less than 5 [23, 37]. This report was varied in both directions, both for consumers regardless of the form of oil consumption and non consumers of palm oil, with no significant difference. Other parameters, in addition to lipid parameters such as sex, BMI, deserve to be explored to better objectify the impact of palm oil on the ratio total cholesterol / HDL [38]. Zhang et al. [34] reported that even among those who were hyper-cholesterolemic, the palm oil significantly reduced the ratio total cholesterol/HDL. After 04 weeks of dieting with palm oil, there was no significant change in the atherogenic index. Thus, whether patients consumed palm oil or not, that did not change significantly the atherogenic index. This could suggest, in accordance with other studies, that the consumption of palm oil does not influence significantly the cardiovascular risk [38, 39].

Most of the benefits of palm oil on the lipid and lipoprotein profile is said to be linked to the high content of antioxidants, carotenoids, and vitamin E. In fact, tocotrienols and tocopherols represent respectively $70 \%$ and $30 \%$ of vitamin $\mathrm{E}$ found in palm oil $[13,16]$. The tocotrienols are well known in the inhibition of HMG-CoA reductase, a key enzyme in cholesterol biosynthesis. Thus, the palm oil is beneficial in reducing cholesterol thereby controlling serum cholesterol levels in the consumer. Sulli et al. [40] demonstrated that supplementation of the diet in tocopherol and $\beta$-carotene had reduced plasma cholesterol levels in hypercholesterolemic rabbits after 08 weeks of diet. This study confirms previous studies about the benefits of the consumption of palm oil, particularly its protective effects as far as cardiovascular diseases are concerned.

\section{Conclusion}

The Consumption or not of palm oil, as well as the form of consumption after 04 weeks of dieting, had no significant influence on the serum lipid and lipoprotein parameters, and the atherogenic index of patients with ischemic heart disease. The palm oil has helped to lower cholesterol after 04 weeks of dieting (28\% of patient's consumers of refined palm oil and $27.50 \%$ of patient's consumers of the two forms of palm oil). In patient's non consumers of palm oil, $26.67 \%$ had hypocholesterolemia with no significant difference. It would not therefore make any sense to consider palm oil responsible for the occurrence of cardiovascular diseases namely ischemic heart diseases; this because palm oil has rather beneficial effects on the cardiovascular system. The study, although preliminary, has allowed showing the harmfulness of palm oil in patients with ischemic heart disease, consumers or non consumers.

\section{References}

[1] Organisation Mondiale de la Santé. Principales causes de mortalité dans le monde; les maladies cardio-vasculaires sontelles la principale cause de décès partout dans le monde? [Internet]. Genève: OMS [consulté le 21/03/2016]. Disponible sur : www.who.int/mediacentre/factsheets/fs310/fr/index $2 . h t m l$

[2] DO Abegunde, T Adam. The burden and costs of chronic diseases in low-income and middle-income countries. Lancet 370, 2007, pp. 1929-38.

[3] TA Gaziano. Reducing the growing burden of cardiovascular disease in the developing world. Health Aff 26 (1), 2007, pp. 13-24.

[4] M Diao, M Sarr, A Kane, A Kane, F Damorou, D Balde, Working Group on Tropical Cardiology, Société Française de Cardiologie. Optimizing the management of acute coronary syndromes in sub-Saharan Africa: A statement from the AFRICARDIO 2015 Consensus Team. Arch Cardiovasc Dis, 109 (6-7), 2016, pp. 376-83.

[5] SV Shah, AM Shukla, C Bose, AG Basnakian, M Rajapurkar. Recent advances in understanding the pathogenesis of atherosclerosis in CKD patients. J Ren Nutr, vol 25 (2), 2015, pp. 205-8.

[6] J-L Bordeau. Oxidative stress in the atherosclerotic process. Paris: Elsevier; 2006. P144-50.

[7] A Mancini, E Imperlini, E Nigro, C Montagnese, A Daniele, S Orrù, $\mathrm{P}$ Buono. Biological and nutritional properties of palm oil and palmitic acid: Effects on health. Molecules 20 (9), 2015, pp. 17339-61.

[8] L'huile de palme est-elle mauvaise pour la santé? la santé par les aliments $>$ Risque santé, www.topsanté.com consulté le $05 / 03 / 2016$

[9] MP Lehucher-Michel, JF Lesgards, O Delubac. stress oxydant et pathologies humaines, bilan et perspectives préventives. Presse Med, 30 (21), 2001, pp. 1076-81. 
[10] M Satge, P J Toury. Alimentation et pathologie nutritionnelle en Afrique noire. Paris: Maloine; 1974. p204-08.

[11] A BEKE. Evaluation des connaissances sur les valeurs nutritionnelles de l'huile de palme chez les patients ayant l'hypertension artérielle à l'institut de cardiologie d'Abidjan. Thèse Méd. Abidjan, N5935/2015, 119P.

[12] S YAPO. Evaluation de la connaissance nutritionnelle sur l'huile de palme chez les patients porteurs de cardiopathies à l'institut de cardiologie d'Abidjan. Thèse Méd. Abidjan, $\mathrm{N}^{\circ}$ $5931 / 2015,123 p$.

[13] N Wattanapenpaiboon, MW Wahlqvist. Phytonutrient deficiency: the place of palm fruit. Asia Pac J Clin Nutr, 12 (3), 2003, pp. 363-368.

[14] D Pacetti, R Gagliardi, M Balzano, NG Frega, ML Ojeda, M Borrero, A Ruiz, P Lucci. Changes in the fatty acid profile and phospholipid molecular species composition of human erythrocyte membranes after hybrid palm and extra virgin olive oil supplementation. J Agric Food Chem, 64 (27), 2016, pp. 5499-507.

[15] JC Jacquemard. Le palmier à huile. Coll. Agricultures tropicales de poche. Ed : Quae/CTA/Presses agronomiques de Gembloux, 2012, 240p.

[16] PE Ebong, DU Owu, EU Isong. Influence of palm oil (Elaeis guineensis) on health. Plant Foods Hum Nutr, 53 (3), 1999, pp. 209-22.

[17] SF Morigbé. Bilan athérolipidique du sujet ivoirien sain nourri à l'huile de palme en contexte fermé non domestique. Thèse Méd Abidjan, N²796/2001, 128p.

[18] AA Monde. Caractérisations des différentes formes variétales de l'huile de palme de Côte d'Ivoire : Propriétés anti oxydantes. Thèse pour le doctorat de l'Université de Montpellier 2, Ecole Doctorale : Sciences des aliments (SPSA), option Nutrition Santé, Septembre 2011, Université Montpellier 2, Sciences et Techniques du Languedoc, France, 257p.

[19] A Mondé, M-A Carbonneau, F Michel et al. Potential health implication of in vitro human LDL-Vitamin $\mathrm{E}$ oxidation modulation by polyphenols deriving from Côte d'Ivoire's oil palm species. J. Agric. Food Chem, 59, 2011, pp. 9166-9171.

[20] Comité Malaisien sur l'huile de palme. Livre de poche sur les utilisations de l'huile de palme. 6e Ed, 2009, 178p.

[21] Les apports nutritionnels de référence. ANREF. Institute of Medicine (IOM), National Academies Press, Washington D. C, 2006, 560p.

[22] ANSES. Agence nationale de sécurité sanitaire de l'alimentation (anciennement AFSSA). https://www.anses.fr/. Consulté le 13/07/2016.

[23] AE Yapo, M Assayi, NB Aka. Les valeurs de référence de 21 constituants biochimiques sanguins de l'Ivoirien adulte présumé sain. Pub Med Afr, 110, 1990, pp. 49-57.

[24] E Bertrand, WF Muna, SM Diouf, A Ekra, A Kane, S Kingue, P Kombila, M Mbaissoroum, A Niakara, A Ould Eba, AO Sidi Al, Y Yapobi. Cardiovascular emergencies in Subsaharan Africa. Arch Mal Coeur Vaiss, 99 (12), 2006, pp. 1159-65.

[25] A Froment, M Gouton. Hypertension artérielle. In Delahaye JP cardiologie 2e Ed Paris, Masson 2000, pp. 309-329.

[26] Fonds français pour l'alimentation et la santé : Etats des lieux novembre 2012. L'huile de palme : Aspects nutritionnels, sociaux et environnementaux 20p. Disponible sur http://alimentation-sante.org/wpcontent/uploads/2012/12/Etatdeslieux HdP 1112.pdf [Consulté le 11/10/15].

[27] F Coulibaly. Evaluation de la connaissance sur les valeurs nutritionnelles de l'huile de palme chez les patients diabétiques reçus au service d'endocrinologie-diabétologie du CHU de Yopougon et au CADA. [Thèse Med]. Abidjan, UFR Sciences Médicales Université FHB, N5935/2015, 119p.

[28] ES Lega. Evaluation de la connaissance sur les valeurs nutritionnelles de l'huile de palme chez les patients en surpoids et obèses au service de nutrition de l'Institut National de Santé Publique d'Adjamé. [Thèse Méd]. Abidjan, UFR Sciences Médicales Université FHB, N5989/2015, 126p.

[29] EU Onyeali, AC Onwuchekwa, CC Monago et al. Plasma profil lipidique des rats albinos Wistar nourris huile de palme régimes supplémentés. Int J Biol Chem Sci, 10, 2010, pp. 1-7.

[30] AM Ladeia, E Costa-Matos, R Barata-Passos, A Costa Guimarães. A palm oil-rich diet may reduce serum lipids in healthy young individuals. Nutrition, 24 (1), 2008, pp. 11-5.

[31] J Zhang, CR Wang, AN Xue, KY Ge. Effects of red palm oil on serum lipids and plasma carotenoids level in Chinese male adults. Biomed Sci Environ, 16, 2003, pp. 348-354.

[32] S Basu, KS Babiarz, S Brahmi, S Vellakkal, D Stuckler, JD Goldhaber-Fiebert. Palm oil taxes and cardiovascular disease mortality in India: economic-epidemiologic model. BMJ, 347, 2013, pp, 1-9.

[33] J Aranceta, C Perez-Rodrigo. Recommended dietary reference intakes, nutritional goals and dietary guidelines for fat and fatty acids: a systematic review. Br J Nutr, 107 (Suppl 2), 2012, pp. S8-22.

[34] J Zhang, W Ping, W Chunrong, CX Shou, G Keyou. Non hypercholesterolemic effects of a palm oil diet in Chinese adults. J Nutr, 127 (Suppl), 1997, pp. 509S-13S.

[35] E Dauqan, HA Sani, A Abdullah, ZM Kasim. Effect of different vegetable oils (red palm olein, palm olein, corn oil and coconut oil) on lipid profile in rat. Food Nutr Sc, 2, 2011, pp. 253-258.

[36] C-M Boon, M-H Ng, Y-M Choo, S-L Mok. Super, red palm and palm oleins improve the blood pressure, heart size, aortic media thickness and lipid profile in spontaneously hypertensive rats. PLOS ONE | www.plosone.org 8 (2/ e55908), 2013, pp 1-12.

[37] J Sakande, JL Coulibaly, N Njikeutchi et al. Etablissement des valeurs de références de 15 constituants biochimiques sanguins chez l'adulte burkinabé à Ouagadougou [En ligne] In : Annales de biochimie Disponible sur www.jle.com Page consultée le 03/07/16.

[38] EJ Schaefer, P Anthanont, BF Asztalos. High-density lipoprotein metabolism, composition, function, and deficiency. Curr Opin Lipidol, vol 25 (3), 2014, pp. 194-9.

[39] J-M Lecerf. L'huile de palme : aspects nutritionnels et métaboliques. Rôle sur le risque cardiovasculaire. Oléagineux Corps Gras Lipides, 10, 2013, pp 76-84.

[40] KC Sulli, J Sun, DW Girrard et al. Effets de la $\beta$-carotène et du tocophérol sur les niveaux de cholestérol dans les tissus et les triglycérides chez les lapins hypercholesteroleamic. J Nutr Bio Chem, 9, 1998, pp. 344-350. 